\title{
The effect of abo and rh blood group antigens on admission to intensive care unit and mortality in patients with COVID-19 infection
}

\author{
(D) Selçuk Yaylaci' \\ (iD) Hamad Dheir \\ Kubilay işsever ${ }^{1}$ \\ (iD) Ahmed Bilal Genc ${ }^{1}$ \\ (iD) Didar Şenocak ${ }^{1}$ \\ (iD) Havva Kocayigit ${ }^{2}$ \\ (iD) Ertugrul Guclu ${ }^{3}$ \\ (iD) Kezban Suner ${ }^{2}$ \\ (iD) Hasan Ekerbicer ${ }^{4}$ \\ (iDehmet Koroglu
}

\begin{abstract}
1. Sakarya University Faculty of Medicine, Department of Internal Medicine. 2. Sakarya University Education and Research Hospital, Department of Intensive Care.

3. Sakarya University Faculty of Medicine Department of Infectious Diseases.

4. Sakarya University Faculty of Medicine Department of Public Health.

5. Sakarya University Faculty of Medicine Department Medical Microbiology.
\end{abstract}

http://dx.doi.org/10.1590/1806-9282.66.S2.86

\section{SUMMARY}

AIM: The aim of this study is to analyze the prognostic significance of $A B O$ and $R h$ blood group antigens along with various parameters in patients followed-up with the diagnosis of COVID-19.

METHODS: We evaluated 397 patients who were follow-up and treated due to COVID-19 infections. The ages, genders, chronic diseases, $A B O$ and Rh blood group antigens, admission rates to Intensive Care Units (ICU), and mortality rates of the patients were analyzed.

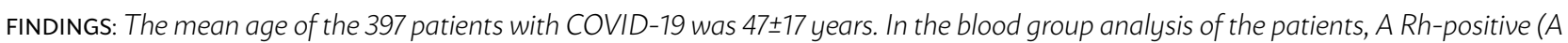
+) was the most frequently seen blood type (176 patients, 44.3\%) followed by O Rh-positive $(0+)(109$ patients, $27,5 \%) ; 38$ patients were Rh negative (Rh -) (9,6\%). 53 of the patients (13,4\%) were followed in ICU and 29 patients died (7,3\%). Neither mortality nor admission to ICU was seen for Rh - group. The comparison of Rh groups concerning the need for ICU admission revealed a significantly high rate of ICU admission in the $R h+$ group $(p=0,011)$, while no significant relationship was found between mortality and Rh antigen ( $p=0,069)$.

CONCLUSION: The most frequently seen blood type among COVID-19 patients was A +. The Rh + blood group was found in all cases who were admitted to ICU and had a death outcome. The Rh + blood group was found in a significantly high number of patients who were admitted to ICU, while no significant relationship was found between mortality and Rh blood group.

KEYWORDS: Coronavirus Infections. ABO Blood-Group System. Rh-Hr Blood-Group System. Intensive care units. Mortality.

\section{INTRODUCTION}

Health care systems, diagnosis, and treatment processes have been struggling with difficulties

concerning the pandemic caused by the novel coronavirus SARS-CoV-2 all over the world. This new 
coronavirus caused 309.827 deaths and 4.664569 confirmed cases as of 16 May 2020, spreading rapidly worldwide' ${ }^{1}$ Thus, there is a need to identify who is at more risk and, according to this, provide protective measures as soon as possible.

Advanced age, chronic diseases, gender, and abnormalities in some laboratory parameters are known risk factors for morbidity and mortality in the course of COVID-19 infections ${ }^{2-4}$. The relationship between SARS-CoV-1 and ABO blood groups was defined firstly in $2005^{5}$. Although another study revealed a relationship between COVID-19 and ABO blood groups, there is not enough evidence in this respect ${ }^{6}$. Yet, the relationship between ABO and Rh blood types and mortality is not clear.

In our study, we aimed to analyze $\mathrm{ABO}$ and $\mathrm{Rh}$ blood group antigens and the effect of these blood group parameters on mortality and ICU admission in patients with COVID-19.

\section{METHODS}

A descriptive cross-sectional study was conducted among 397 COVID-19 patients between 19 March and 19 April 2020. Data such as age, gender, chronic diseases (diabetes mellitus, hypertension, chronic pulmonary diseases, malignant diseases, cardiovascular diseases, chronic renal failure, etc.), ABO and Rh blood type, ICU admission, and mortality of patients were recorded. The mean age, gender, and number of chronic diseases of the patients were analyzed. The distribution of COVID-19 patients according to blood groups was assessed. ICU admission and mortality rates according to $\mathrm{ABO}$ and $\mathrm{Rh}$ blood group of the patients were analyzed.

An ethics committee approval from Sakarya University Medical Faculty was provided for this study (approval number: 71522473/050.01.04/).180

\section{Statistical analysis}

Quantitative data were expressed as mean values $\pm \mathrm{SD}$, medians, and ranges. Qualitative data were expressed as numbers and percentages. After performing the Kolmogorov-Smirnov test to assess the normality of distribution, a nonparametric Mann-Whitney test was used to compare the ages of patients between $\mathrm{Rh}+$ and Rh - groups. The Chi-square or Fisher's exact test was used for categorical variables. P values $<0.05$ were considered statistically significant. Analyses were performed using Statistical Package for the Social Sciences version 20.0 (IBM SPSS Statistics; Armonk, NY, USA).

\section{RESULTS}

The mean age of the 397 patients with COVID-19 was $47 \pm 17.5$ years (min-max: 17-92). Out of these, 176 of the patients were male (44.3\%) and 221 were female (55.7 \%). In the blood group analysis of the patients, A Rh-positive $(\mathrm{A}+)$ was the most common blood type (176 patients, 44.3\%), followed by O Rh-positive (O +) (109 patients, 27.5\%); 53 patients were $\mathrm{B}+(13.4 \%), 25$ patients were $\mathrm{A}-(6.3 \%), 21$ patients were $\mathrm{AB}+(5.3 \%)$, 11 patients were $\mathrm{O}-(2.8 \%), 2$ patients were $\mathrm{B}-(0.5 \%)$ and no patients were $\mathrm{AB}$-. A total of 38 patients were $\mathrm{Rh}-(9.6 \%)$, while 359 patients were $\mathrm{Rh}+(90.4 \%)$. Of all patients, $53(13.4 \%)$ were followed in ICU. In the blood group analysis of the 53 ICU patients, we found that 17 were $\mathrm{O}+(15.6 \%), 8$ were $\mathrm{B}+(15.1 \%), 26$ were $\mathrm{A}+(14.8 \%)$, 2 were $\mathrm{AB}+(9.5 \%)$. The lowest ratio of ICU admission among $\mathrm{Rh}+$ blood group patients was found for the $\mathrm{AB}+$ group $(9.5 \%)$. In the analysis of mortality ratios according to blood types (29 dead patients, $7.3 \%$ ), it was found that 5 of $\mathrm{B}+$ patients $(9.4 \%), 15$ of $\mathrm{A}+$ patients $(8.5 \%)$, 8 of $\mathrm{O}+$ patients $(7.3 \%), 1$ of $\mathrm{AB}+$ patients $(4.8 \%)$ died in ICU. Neither mortality nor admission to ICU was seen for the Rh - group (Table 1). The variables of age, gender, and having at least one chronic disease were statistically similar for Rh + and Rh - patients (Table 2). In the comparative analysis of Rh groups regarding ICU admission, a statistically significant relationship was found between having Rh + blood group and the ICU admission rate $(p=0.011)$. Nevertheless, in the comparison analysis of $\mathrm{Rh}$ groups regarding mortality rates, no significant relationship was found between $\mathrm{Rh}$ factor and mortality rates $(p=0.069)$. The lowest mortality

TABLE 1. DISTRIBUTION OF ABO AND RH BLOOD GROUPS, MORTALITY AND ICU ADMISSION RATES OF COVID-19 PATIENTS

\begin{tabular}{l|l|l|l|l|l|l}
$\begin{array}{l}\text { BLOOD } \\
\text { GROUP }\end{array}$ & $n$ & $\%$ & \multicolumn{2}{l|}{ ICU (n-\%) } & \multicolumn{2}{l}{ Mortality } \\
\hline O Rh - & 11 & 2,8 & 0 & 0 & 0 & 0 \\
\hline O Rh + & 109 & 27,5 & 17 & 15,6 & 8 & 7,3 \\
\hline A Rh - & 25 & 6,3 & 0 & 0 & 0 & 0 \\
\hline A Rh + & 176 & 44,3 & 26 & 14,8 & 15 & 8,5 \\
\hline AB Rh + & 21 & 5,3 & 2 & 9.5 & 1 & 4,8 \\
\hline AB Rh - & 0 & 0 & 0 & 0 & 0 & 0 \\
\hline B Rh - & 2 &, 5 & 0 & 0 & 0 & 0 \\
\hline B Rh + & 53 & 13,4 & 8 & 15,1 & 5 & 5,9 \\
\hline Total & 397 & 100 & 53 & 13,4 & 29 & 7,3 \\
\hline
\end{tabular}


ratio was found in $\mathrm{AB}+$ patients among the $\mathrm{Rh}+$ blood group (4.8\%, Table 3). None of the comparative analyses of $\mathrm{O}, \mathrm{A}, \mathrm{B}$, and $\mathrm{AB}$ groups with other blood groups revealed a significant relationship with ICU admission and mortality (Table 4).

\section{DISCUSSION}

Advanced age, comorbid diseases, male gender, and high levels of lactate dehydrogenase (LDH), neutrophil/lymphocyte ratio, and D-dimer are known as poor prognostic factors for COVID-19 infection ${ }^{3,4,7}$. The pathogenesis and prognostic indicators of COVID-19 disease are still not fully known. İn this study, we investigated whether there is an association between COVID-19 disease progression and blood groups. The surface of red blood cells is covered with antigens (sugars and proteins) which are integrated with membrane proteins and lipids. ABO and Rh blood type systems are crucial for safe blood and organ transplantation processes. Blood group antigens exist on the surface of each erythrocyte. If there is only antigen $\mathrm{A}$ on the erythrocyte, it becomes group $\mathrm{A}$, and if there is only antigen B on the erythrocyte, it becomes group B. If antigen $A$ and $B$ exist at the same time on the surface of the erythrocyte, it becomes group $\mathrm{AB}$; while if there is no antigen on the surface of that erythrocyte, it becomes group $\mathrm{O}$. On the other hand, reciprocal antibodies exist in the plasma of human body. Group B antibody is present in the plasma of the A blood group while A antibody is present in the plasma of the B blood group. A and B antibody exist at the same time in the plasma of the $\mathrm{O}$ blood group. $\mathrm{Rh}$ antigens are also located on the membrane of erythrocytes and consist of three pairs, i.e., Dd, Cc, and Ee. Besides these, there are many other antigens such as Duffy,

TABLE 2. COMPARISON OF AGES, GENDERS, AND HAVING AT LEAST ONE CHRONIC DISEASE, ACCORDING TO THE PATIENT'S RH FACTORS ( $\mathrm{N}=397)$

\begin{tabular}{l|l|l|l}
\hline Patient Characteristics & Rh+. n: $359(90.4 \%)$ & Rh-. n: $38(9.6 \%)$ & P \\
\hline $\begin{array}{l}\text { Mean age } \pm \text { SD } \\
\text { (min.-med.-max) }\end{array}$ & $\begin{array}{l}49.6 \pm 17.5 \\
(17.0-47.0-92.0)\end{array}$ & $\begin{array}{l}44.4 \pm 15.9 \\
(19.0-43.0-85.0)\end{array}$ & $0.099^{*}$ \\
\hline Sex (M/F) & $176 / 221(45.7 \% / 54.3 \%)$ & $12 / 26(31.6 \% / 68.4 \%)$ & $0.136^{\star *}$ \\
\hline At least one chronic disease (yes/no) & $132 / 226(36.9 \% / 63.1 \%)$ & $13 / 25(34.2 \% / 65.8 \%)$ & ${ }^{* *} 0.883$ \\
\hline
\end{tabular}

* Mann-Whitney test was used. ${ }^{\star \star}$ Chi Square test was used.

TABLE 3. ANALYSIS OF ICU ADMISSION AND MORTALITY RATES ACCORDING TO PATIENTS' RH FACTORS

\begin{tabular}{|c|c|c|c|c|c|c|}
\hline \multirow[t]{2}{*}{$\mathrm{Rh}$} & \multicolumn{2}{|c|}{ ICU admission } & \multirow[t]{2}{*}{$\mathrm{p}$} & \multicolumn{2}{|l|}{ Mortality } & \multirow[t]{2}{*}{$\mathrm{p}$} \\
\hline & Non $(\%)$ & Yes n (\%) & & No n (\%) & Yes n (\%) & \\
\hline $\mathrm{Rh}-$ & $38(100.0 \%)$ & $0(0.0 \%)$ & \multirow{3}{*}{0.011} & $38(100.0 \%)$ & $0(0.0 \%)$ & \multirow{3}{*}{0.069} \\
\hline $\mathrm{Rh}+$ & $306(85.2 \%)$ & $53(14.8 \%)$ & & $330(91.9 \%)$ & $29(8.1 \%)$ & \\
\hline Total & 344 (86.6 \%) & $53(13.4 \%)$ & & 368 (92.7 \%) & $29(7.3 \%)$ & \\
\hline
\end{tabular}

${ }^{\star}$ Chi-Square test was used.

TABLE 4. COMPARISON OF EACH BLOOD GROUP WITH OTHER BLOOD GROUPS RELATING TO ICU ADMISSION AND MORTALITY RATES

\begin{tabular}{|c|c|c|c|c|c|c|}
\hline \multirow[t]{2}{*}{ Blood groups } & \multicolumn{2}{|c|}{ ICU Admission } & \multirow[t]{2}{*}{$\mathrm{p}$} & \multicolumn{2}{|l|}{ Mortality } & \multirow[t]{2}{*}{ p } \\
\hline & No n (\%) & Yes n (\%) & & Non $(\%)$ & Yes n (\%) & \\
\hline Group $\bigcirc$ & $103(85,8 \%)$ & $17(14.2 \%)$ & \multirow[t]{2}{*}{$0.877^{\star}$} & $112(93.3 \%)$ & $8(6.7 \%)$ & \multirow[t]{2}{*}{$0.911^{\star}$} \\
\hline Other & $241(87.0 \%)$ & $36(13.0 \%)$ & & $256(92.4 \%)$ & $21(7.6 \%)$ & \\
\hline Group A & $175(87.1 \%)$ & $26(12.9 \%)$ & \multirow[t]{2}{*}{$0.922^{*}$} & $186(92.5 \%)$ & $15(7.5 \%)$ & \multirow[t]{2}{*}{$0.903^{*}$} \\
\hline Other & $169(86.2 \%)$ & $27(13.8 \%)$ & & $182(92.9 \%)$ & $14(7.1 \%)$ & \\
\hline Group B & $47(85,5 \%)$ & $8(14.5 \%)$ & \multirow[t]{2}{*}{$0.946^{*}$} & $50(90.9 \%)$ & $5(9.1 \%)$ & \multirow[t]{2}{*}{$0.577^{\star *}$} \\
\hline Other & $297(86.8 \%)$ & $45(13.2 \%)$ & & $318(93.0 \%)$ & $24(7.0 \%)$ & \\
\hline Group AB & $19(90.5 \%)$ & $2(9.5 \%)$ & \multirow[t]{2}{*}{$1.000^{\star *}$} & $20(95.2 \%)$ & $1(4.8 \%)$ & \multirow[t]{2}{*}{$1.000^{* \star}$} \\
\hline Other & $325(86.4 \%)$ & $51(13.6 \%)$ & & $348(92.6 \%)$ & $28(7.4 \%)$ & \\
\hline Total & $344(86.6 \%)$ & $53(13.4 \%)$ & & $368(92.7 \%)$ & $29(7.3 \%)$ & \\
\hline
\end{tabular}

${ }^{*}$ Chi-Square test was used.* Fisher's Exact Test was used. 
Lewis, Kidd, MNS, and Kell ${ }^{8}$. Additionally, some red blood cell surface antigens have clinically important cellular functions, while some others are targets for immune system attacks in the course of infections ${ }^{8}$.

For blood donors, the $\mathrm{O}$ blood group was evaluated as a higher risk in terms of HIV and Hepatitis B infection $^{9}$. In another study, blood group $\mathrm{O}$ and $\mathrm{Rh}+$ were associated with a higher risk of Hepatitis B infection ${ }^{10}$.

In our study, we tried to analyze the frequencies of $\mathrm{ABO}$ and Rh blood types in COVID-19 patients and the relationships of these frequencies with ICU admissions and mortality rates. To our knowledge, no study published in peer-reviewed journals related to this subject could be found in the literature. A few preprint or non-refereed studies have been published so far. Blood group A was reported to be associated with a higher risk of COVID-19, and blood group O was reported to be associated with a lower risk of COVID-19 in these studies $^{6,11,12}$. People with O blood group were reported to be at lower risk for SARS coronavirus infection in a study published in $2005^{5}$. It is stated that the A-type antibody may provide protection by inhibiting the interaction between the virus and ACE2 receptor ${ }^{13}$. In a series of blood group analyses performed in our country, the frequencies of blood groups $\mathrm{A}, \mathrm{B}, \mathrm{AB}$, and O were $40-45 \%, 15-19 \%, 5-14 \%$, and $28-36 \%$, respectively. The frequency of Rh positivity was reported as $84-92 \%$, while the frequency of Rh negativity was reported as $8-16 \%{ }^{14}$. In a study including 13116 cases from our local region, frequencies of blood groups were analyzed and frequencies of blood types $\mathrm{A}+, \mathrm{O}+$, and $\mathrm{Rh}$ - were found as $38.1 \%, 30.2 \%$, and $15.2 \%$, respectively ${ }^{15}$. A comparison of the data from these studies with our data reveals a quite similar distribution of blood groups, as well as a higher frequency of blood group A in COVID-19 patients. The detection of a high frequency of COVID-19 patients with blood group A may be caused by the deficiency of the A-type antibody protection, but it is not clear yet. The mechanism behind the susceptibility of blood group A to COVID-19 infection needs advanced analysis to be well understood.

In our study, no relationship was found between blood groups and mortality or ICU admission. The variables of age, gender, and having at least one chronic were similar in $\mathrm{Rh}+$ and $\mathrm{Rh}-$ patients. Regarding ICU admission, a statistically significant relationship was found between having $\mathrm{Rh}+$ factor and the ICU admission rate $(\mathrm{p}=0,011)$, and no significant relationship was found between $\mathrm{Rh}$ factor and mortality rates $(p=0,069)$. Neither comparison analysis of $\mathrm{O}, \mathrm{A}, \mathrm{B}$, and $\mathrm{AB}$ groups with other blood groups revealed a significant relationship with ICU admission and mortality.

According to these results, we can state that patients with A blood group might be at higher risk for COVID-19 infection and $\mathrm{Rh}+$ patients might show poor outcomes as they are at higher risk for ICU admission. More multicenter researches with a higher number of cases are needed to clarify the effects of $\mathrm{ABO}$ and Rh blood types on the prognosis.

\section{CONCLUSION}

A specific blood group might face more risk of COVID-19 infection. More need for ICU admission is seen in Rh + COVID-19 patients. Although statistically insignificant, all cases in which the outcome was death were found in the $\mathrm{Rh}+$ group.

\section{Limitations}

Our study has some limitations. It was conducted in a single center and has a relatively small number of patients.

\section{Acknowledgments}

We would like to thank our supervisors, Prof. Oguz Karabay, Prof. Yakup Tomak, and Prof. Ali Fuat Erdem. We thank all the medical, nursing, and technical staff from the Sakarya University Training and Application Hospital, for their dedicated care of patients during the COVID-19 pandemic.

\section{Conflict of interest}

The authors declare that they have no competing interests. Ethical standard: This study was conducted in accordance with the Declaration of Helsinki.

The study was approved by the Ethics Committee of Sakarya University Medical Faculty.

\section{Author's Contribution}

SY, HD: Data analysis and interpretation, drafting the article, critical revision of the article, final approval of the version; KI, ABG, DS, HK: Data collection, conception or design of the work, data analysis and interpretation, critical revision of the article, final approval of the version; EG, KS, HE, MK: Data analysis and interpretation, final approval of the version to be published. 


\section{RESUMO}

OBJETIVO: O objetivo deste estudo é analisar o significado prognóstico dos antígenos do grupo sanguíneo ABO e Rh, juntamente com vários parâmetros em pacientes acompanhados com o diagnóstico de COVID-19.

MÉTODOS: Foram avaliados 397 pacientes que foram acompanhados e tratados devido à infecção por COVID-19. Foram analisadas as idades, gêneros, doenças crônicas, antígenos do grupo sanguíneo $A B O$ e Rh, taxas de internação em unidades de terapia intensiva (UTI) e taxas de mortalidade dos pacientes.

A idade média de 397 pacientes com COVID foi de $47 \pm 17$ anos. Na análise do grupo sanguíneo dos pacientes, $A$ Rh positivo $(A+)$ foi o tipo sanguíneo mais frequentemente observado (176 dos pacientes, 44,3\%), seguido pelo O Rh positivo $(0+)(109$ dos pacientes, 27,5\%) 38 dos pacientes eram Rh negativos (Rh -) (9,6\%). 53 dos pacientes (13,4\%) foram acompanhados em UTI e 29 faleceram (7,3\%). Não houve mortalidade nem admissão na UTI para o grupo Rh. A comparação dos grupos Rh quanto à necessidade de admissão na UTI revelou uma taxa significativamente alta de admissão na UTI no grupo $R h+(p=0,011)$, enquanto não foi encontrada relação significativa entre mortalidade e antígeno $\operatorname{Rh}(p=0,069)$.

CONCLUSÃO: O tipo sanguíneo mais frequentemente observado foi o A + entre os pacientes com COVID-19. O grupo sanguíneo Rh + foi encontrado em todos os casos admitidos na UTI e com evolução mortal. O grupo sanguíneo $R h+$ foi encontrado em um número significativamente alto de pacientes internados na UTI, enquanto nenhuma relação significativa foi encontrada entre a mortalidade e o grupo sanguíneo $R h$.

PALAVRAS-CHAVE: Infecções por Coronavirus. Sistema ABO de Grupos Sanguíneos. Sistema do Grupo Sanguíneo Rh-Hr. Unidades de terapia intensive. Mortalidade.

\section{REFERENCES}

1. World Health Organization. Coronavirus disease (COVID-2019) situation reports 94. Geneva: World Health Organization; 2020. [cited 2020 May 30]. Available from: https://www.who.int/docs/default-source/coronaviruse/ situation-reports/20200423-sitrep-94-COVID-19.pdf?sfvrsn=b8304bf0_4

2. Chen R, Liang W, liang M, Guan W, Zhan C, Wang T, et al; Medical Treatment Expert Group for COVID-19. Risk factors of fatal outcome in hospitalized subjects with coronavirus disease 2019 from a nationwide analysis in China. Chest. 2020;S0012-3692(20)30710-8.

3. Yang AP, Liu JP, Tao WQ, Li HM. The diagnostic and predictive role of NLR, d-NLR and PLR in COVID-19 patients. Int Immunopharmacol. 2020;84:106504

4. Li R, Tian J, Yang F, Lv L, Yu J, Sun G, et al. Clinical characteristics of 225 patients with COVID-19 in a tertiary hospital near Wuhan, China. J Clin Virol. 2020;127:104363.

5. Cheng Y, Cheng G, Chui CH, Lau FY, Chan PKS, Ng MHL, et al. ABO blood group and susceptibility to severe acute respiratory syndrome. JAMA. 2005;293(12):1450-1.

6. Zhao J, Yang Y, Huang H, Li D, Gu D, Lu X, et al. Relationship between the ABO blood group and the COVID-19 susceptibility. medRxiv preprint. doi: https://doi.org/10.1101/2020.03.11.20031096

7. Li X, Xu S, Yu M, Wang K, Tao Y, Zhou Y, et al. Risk factors for severity and mortality in adult COVID-19 inpatients in Wuhan. | Allergy Clin Immunol. 2020;S0091-6749(20)30495-4.

8. Uhl L. Red blood cell antigens and antibodies. Uptodate. 2020. [cited 2020 May 30]. Available from: https://www.uptodate.com/contents/ red-blood-cell-antigens-and-antibodies
9. Siransy LK, Nanga ZY, Zaba FS, Tufa NY, Dasse SR. ABO/Rh blood groups and risk of HIV infection and hepatitis B among blood donors of Abidjan, Côte D'ivoire. Eur J Microbiol Immunol. 2015;5(3):205-9.

10. Liu J, Zhang S, Liu M, Wang Q, Shen H, Zhang Y. Distribution of $A B O / R h$ blood groups and their association with hepatitis $B$ virus infection in 3.8 million Chinese adults: a population-based cross-sectional study. J Viral Hepat. 2018;25(4):401-11.

11. Zeng $X$, Fan H, Lu D, Huang F, Meng $X$, Li Z, et al. Association between $A B O$ blood groups and clinical outcome of coronavirus disease 2019: evidence from two cohorts. medRxiv preprint. doi: https://doi.org/10.1101/2 020.04.15.20063107.

12. Fan H, Zhang L, Huang B, Zhu M, Zhou Y, Zhang H, et al. Retrospective analysis of clinical features in 101 death cases with COVID-19. medRxiv preprint. doi: https://doi.org/10.1101/2020.03.09.20033068.

13. Guillon P, Clément M, Sébille V, Rivain JG, Chou CF, Ruvoën-Clouet N, et al. Inhibition of the interaction between the SARS-CoV spike protein and its cellular receptor by anti-histo-blood group antibodies. Glycobiology. 2008;18(12):1085-93.

14. Akın G, Dostbil N. Türkiye'de kan grubu araştırmaları. Ankara Üniversitesi Dil ve Tarih-Coğrafya Fakültesi Dergisi. 2005;45(2):1-15.

15. Cekdemir D, Ergenc H, Ucar A, Cekdemir YE, Gunduz M, Oren AC, et al. Blood groups distributions of donors/patients in a tertiary hospital. Sakarya Med I. 2018;8(4):753-8. 